\title{
Holocene sea-level changes along the Mediterranean coast of Israel, based on archaeological observations and numerical model
}

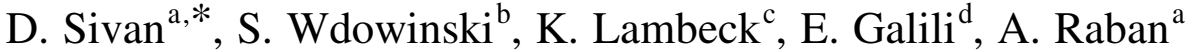 \\ ${ }^{a}$ Department of Maritime Civilizations and Center for Maritime Studies, University of Haifa, Mount Carmel Haifa 31905, Israel \\ ${ }^{\mathrm{b}}$ Department of Geophysics and Planetary Sciences, Tel Aviv University, Ramat Aviv 69978, Israel \\ ${ }^{\mathrm{c}}$ Research School of Earth Sciences, The Australian National University, Canberra ACT 0200, Australia \\ ${ }^{\mathrm{d}}$ Marine Archaeology Branch, Israel Antiquities Authority P.O. Box 180, Atlit 30350, Israel
}

Received 24 December 1999; accepted for publication 12 September 2000

\begin{abstract}
Local sea-level curves reflect global eustatic changes, regional isostatic adjustments of the crust to changing ice and ocean volumes and tectonically controlled crustal movements. In this study, we evaluate the relative contribution of each of these factors to the Holocene sea-level curve of the Mediterranean coast of Israel. We use archaeological data as constraints on palaeo sea levels and we then compare the observational limits with isostatic models for sea-level change across the region. The isostatic model includes the contribution arising from the relative minor increase in ocean volumes for the past 6000 years due to residual melting of ice sheets, the effect of the changing shape of the ocean basin, the time dependence of shorelines as sealevel changes and the changing surface area occupied by ice sheets. Differences, if significant, between the observed and predicted change are interpreted as being of tectonic origin. The archaeological observations and the model sea-level curve, along the Mediterranean coast of Israel were found to be generally consistent and any discrepancies lie within the uncertainties of both values. Our model predicted that 8000 years ago sea level at the Israel coast was at about $-13.5 \pm 2 \mathrm{~m}$, whereas the archaeological data place it at $-16.5 \pm 1 \mathrm{~m}$. By $7000 \mathrm{BP}$ the predicted level has risen to about $-7 \pm 1 \mathrm{~m}$ consistent with the archaeological evidences. According to both observations and predictions sea level was still lower than -3 to $-4.5 \mathrm{~m}$ at $6000 \mathrm{BP}$ and remained below its present level until about 3000-2000 BP. The comparison between the model sea-level curve and the archaeological observations also enable to conclude that the average rate of vertical tectonic movement for the last 8000 years, at the Carmel coast, Israel, has been less than $0.2 \mathrm{~mm} /$ year. (c) 2001 Elsevier Science B.V. All rights reserved.
\end{abstract}

Keywords: sea-level change; isostasy; underwater and coastal archaeology; Holocene; coast of Israel

\section{Introduction}

Studies of sea-level positions through time show major differences among curves for different locations in the world as summarized, for example, by Pirazzolli (1991), underscoring the importance of regional factors in shaping sea-level change. Local sea-level

\footnotetext{
* Corresponding author.

E-mail address: dsivan@ research.haifa.ac.il (D. Sivan).
}

curves (e.g. Van Andel and Shackleton, 1982) reflect global eustatic changes, regional isostatic adjustments of the crust to changing ice and ocean volumes and regional, tectonically controlled, crustal movement. In this study, we evaluate the relative contribution of each of these factors to the Holocene sea-level curve of the Mediterranean coast of Israel. For this purpose, we use archaeological data as constraints on palaeo sea levels and, we then compare the observational limits with isostatic models for sea-level 


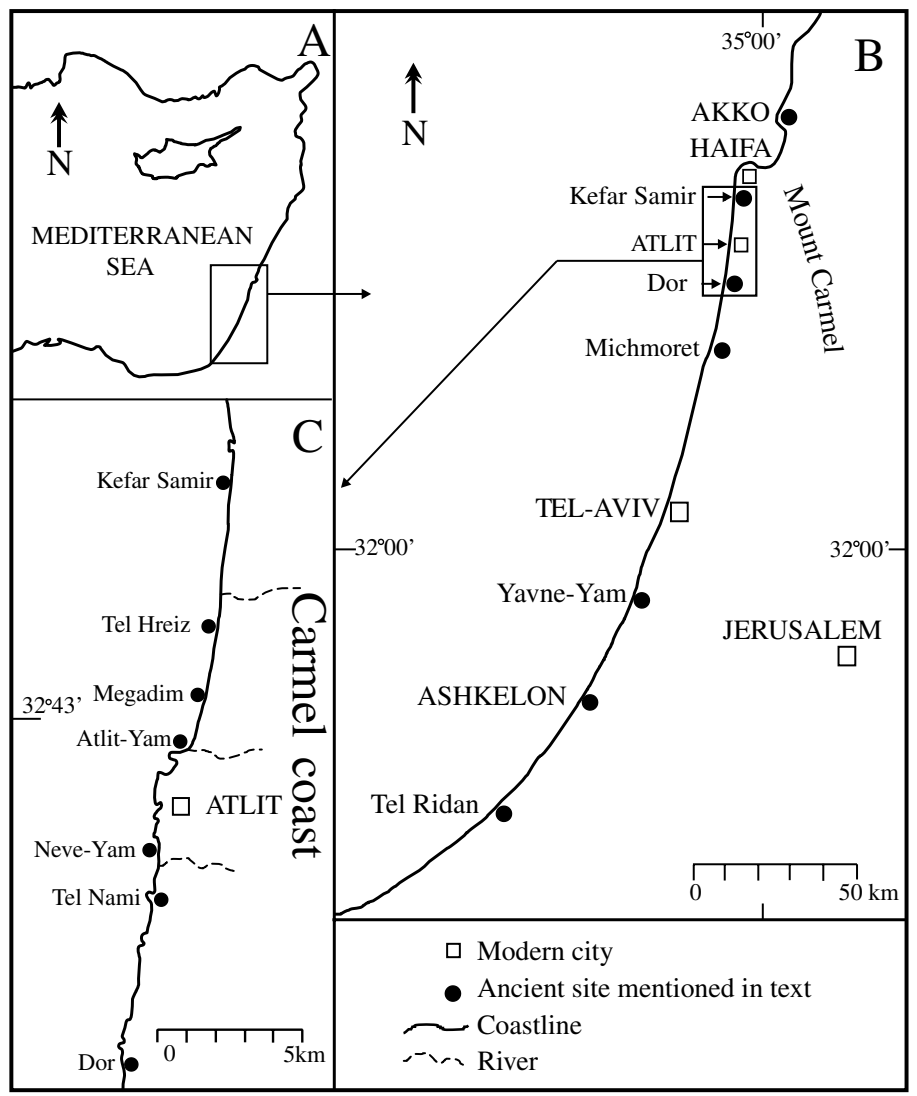

Fig. 1. Location maps: (a) The East Mediterranean region. (b) Archaeological sites mentioned along the Mediterranean coast of Israel. (c) Sites along the Carmel coast relevant to palaeo sea-level studies.

change across the region. Differences, if significant, between the observed and predicted change are then interpreted as being of tectonic origin. (We refer to all non-glacio-hydro-isostatic displacements of the crust as the tectonic contribution. Thus, this term may include vertical displacements associated with plate tectonic forces, with offshore sediment loading, as well as any local displacements caused by, for example, sediment compaction.)

Underwater and coastal archaeological research conducted along the Mediterranean coast of Israel (Fig. 1) reveals significant evidence of sea-level change during the Holocene. Submerged prehistoric sites from Late Pre-Pottery Neolithic ( $~ 8000 \mathrm{BP})$ to Late Chalcolithic ( $\sim 5200 \mathrm{BP})$, as well as younger remains of manmade structures and shipwrecks from Middle Bronze age ( $\sim 4000$ to $\sim 3500 \mathrm{BP})$ and later, suggest that a rapidly rising sea advanced over the coastal shelf, covered and flooded prehistorical settlements and buried the sites under sand (Galili et al., 1988; Galili and Weinstein-Evron, 1985). In recent decades, intensive erosion of the immediate offshore sediments has led to the exposure of the underwater archaeological sites. Underwater and coastal surveys and excavations of these newly exposed relicts provided new data for reconstructions of palaeo sea levels. Three types of underwater archaeological finds are used in this research as indicators for sea-level change: (i) submerged prehistoric settlements; (ii) water-wells; and (iii) assemblages of shipwrecks. On land there are waterfront man-made structures that bear a well-defined relation to sea level such as slipways, flushing channels, piscinas, salinas and coastal wells. In this research, we use only welldated archaeological data and consider them as either upper or lower bounds of the inferred sea-level change (Tables 1 and 2). 
Table 1

Underwater archaeological constraints on palaeo sea level from submerged prehistoric settlements of early Holocene age, Carmel coast, Israel (all ages are ${ }^{14} \mathrm{C}$ uncalibrated dates)

\begin{tabular}{|c|c|c|c|c|c|}
\hline Site & $\begin{array}{l}\text { Age }(\mathrm{BP}) \\
\left({ }^{14} \mathrm{C} \text { years }\right)\end{array}$ & Dated material & $\begin{array}{l}\text { Upper bound } \\
(\mathrm{m})\end{array}$ & $\begin{array}{l}\text { Lower bound } \\
(\mathrm{m})\end{array}$ & Remarks \\
\hline Atlit Yam & $\begin{array}{l}8140 \pm 120 \\
8000 \pm 90\end{array}$ & Charcoal & $\begin{array}{l}-14 \\
-14.5\end{array}$ & -16.5 & $\begin{array}{l}\text { Underwater } \\
\text { Pre-Pottery Neolithic dwelling, at }-8 \text { to }-12 \mathrm{~m} \\
\text { Well base at }-15.5 \mathrm{~m}\end{array}$ \\
\hline Kefar Samir & $\begin{array}{l}6830 \pm 60 \\
6830 \pm 80 \\
7540 \pm 370 \\
7380 \pm 310\end{array}$ & $\begin{array}{l}\text { Wooden beam } \\
\text { Wood }\end{array}$ & -6 & -8 & $\begin{array}{l}\text { Two wood samples from water well. The well base is at }-7 \mathrm{~m} \\
\text { Two wooden courses of a pit whose top is at }-5 \mathrm{~m}\end{array}$ \\
\hline Megadim & $\begin{array}{l}6310 \pm 70 \\
7060 \pm 70\end{array}$ & $\begin{array}{l}\text { Mandible } \\
\text { Clay }\end{array}$ & $\begin{array}{l}-5.5 \\
-5.5\end{array}$ & & $\begin{array}{l}\text { A mandible from a pit at }-3.5 \mathrm{~m} \\
\text { Organic clay from a depth of } 10 \mathrm{~cm} \text { near the pit }\end{array}$ \\
\hline $\begin{array}{l}\text { Neve Yam } \\
\text { Tel Hreiz }\end{array}$ & $\begin{array}{l}6860 \pm 60 \\
6270 \pm 50\end{array}$ & $\begin{array}{l}\text { Charcoal } \\
\text { Wood }\end{array}$ & $\begin{array}{l}-7 \\
-4.5\end{array}$ & & $\begin{array}{l}\text { The site extends up to }-5 \mathrm{~m} \\
\text { Wooden fence at }-2.5 \mathrm{~m}\end{array}$ \\
\hline
\end{tabular}

Previous studies of some of this evidence for the past 8000 years have shown that the sea level along the Mediterranean coast of Israel (Fig. 2), rose rapidly until about $7500 \mathrm{BP}$ (Galili and Nir, 1993) and perhaps up to 6000 BP (Galili et al., 1988), followed by a less rapid rise up to the present. However, some studies suggest that at about 3500 years ago sea level may have been higher than today (Sneh and Klein, 1984; Raban and Galili, 1985; Raban, 1995), but most research points to sea level lower than present, during historical periods.

In relatively tectonically stable areas far from former ice sheets the primary reason for fluctuations of sea level throughout the last 20,000 years has been the exchange of mass between the ice sheets and the oceans; as the Late Pleistocene ice sheets melted, water was added to the oceans and global rise in sea-level occurred. This is the eustatic component. But in response to the changing surface loads of ice and water, the crust responds by uplift under the formerly ice-loaded areas, and by subsidence where the ocean load increases. Thus the total sea-level change is the sum of these eustatic and isostatic contributions. Near the centers of the former ice sheets the crust is uplifted at a rate that is faster than the eustatic rise and here the sea retreats from the land, even when the overall volume of the ocean is increasing and global sea level is rising. Immediately beyond the areas of glaciation, the crust subsides and Holocene sea-level change tends to be greater than the

Table 2

Typological dating of land and underwater sites, shipwrecks and inland water-wells as constraints on Late Holocene sea level, Israel (stone anchors of Late Bronze to Hellenistic period (3200-2000 BP), from many sites along the Israel coast, imply that sea level cannot be lower than $-3 \mathrm{~m}$ during this period)

\begin{tabular}{lllll}
\hline Site & Age (BP) & $\begin{array}{l}\text { Upper bound } \\
(\mathrm{m})\end{array}$ & $\begin{array}{l}\text { Lower bound } \\
(\mathrm{m})\end{array}$ & Remarks \\
\hline Tel Nami & $4000-3750$ & +0.3 & -1.7 & The MB2 well base is at $-0.7 \mathrm{~m}$ \\
Dor & $3200-3000$ & -0.4 & -1 & LB2 quays their bases are at $-0.4 \mathrm{~m}$ \\
& $2300-2200$ & -0.2 & -1.4 & LB2 well base at $-0.4 \mathrm{~m}$ \\
Michmoret & $2600-2300$ & -0.4 & -2.4 & Hellenistic flushing channel, base at $-1.6 \mathrm{~m}$ and erosive notch at $-0.2 \mathrm{~m}$ \\
Yavne Yam & $2300-2000$ & +0.3 & -1.7 & The Persian well base is at $-1.4 \mathrm{~m}$
\end{tabular}



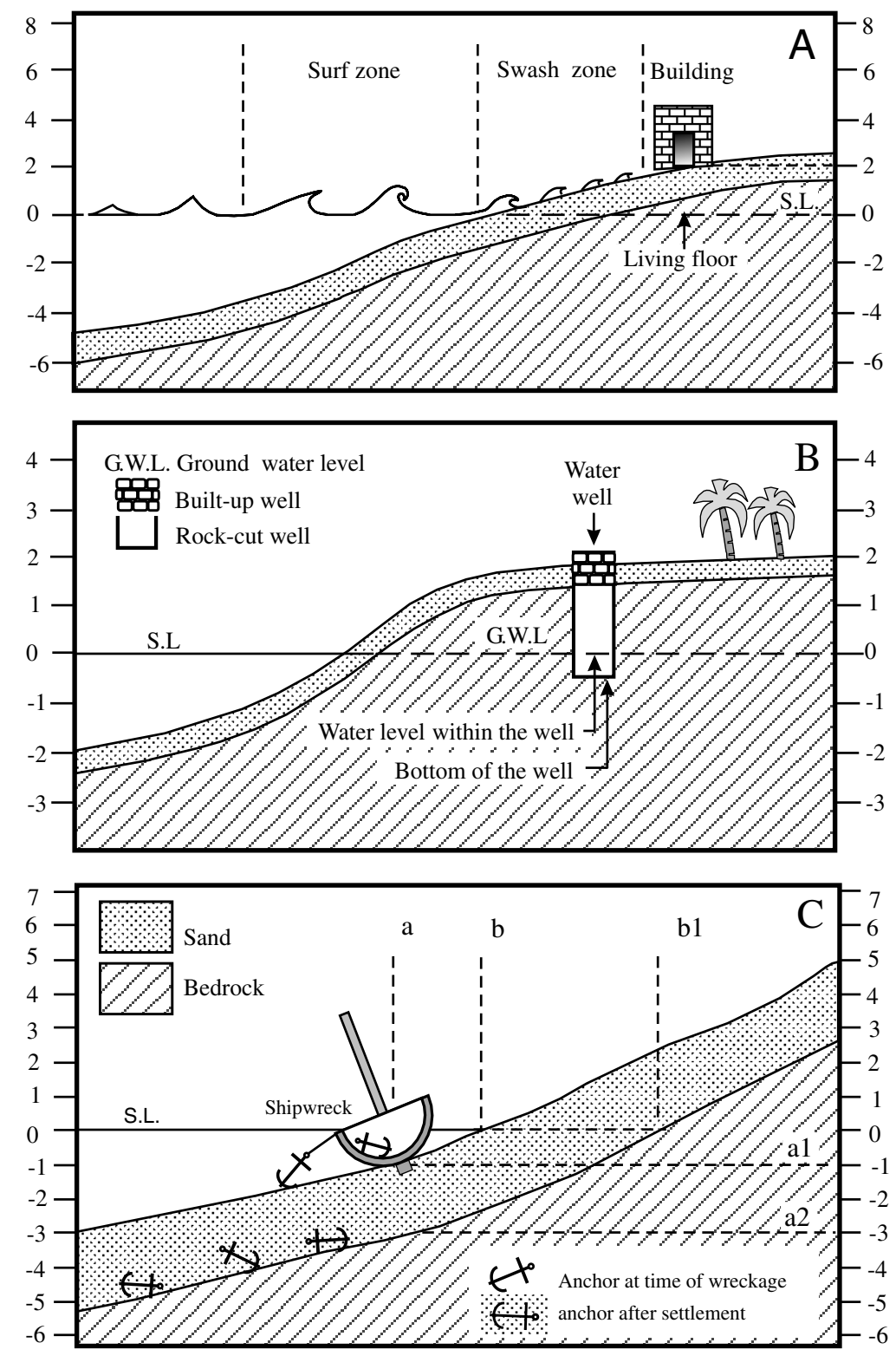

Fig. 2. Three examples of archaeological sea-level indicators. (a) Living floors provide upper bound. In this research, palaeo sea level is assumed to have stood at least $2 \mathrm{~m}$ below the floor levels so as to be beyond the swash zone. (b) Ancient wells provide upper and lower bounds on sea level. Coastal wells have to be dug to a minimal depth in order to avoid salinization but they still have to be effective at the lowest water levels. The inferred bottom depth of ancient coastal wells along the Israeli coast was $0.3-0.4 \mathrm{~m}$ below the water table (in order to draw clear water when using jars). This implies that the base of the well was about 0.1-0.2 $\mathrm{m}$ above mean sea level at the usage period. For lower bound we adopt a level of $1 \mathrm{~m}$ below sea level. (c) The dispersion line of shipwrecks and heavy objects from the wreckage approximates the palaeocoastline. Analogous to modern observations, we assume that approximately 1.5-2 m of sand covered the wrecked objects and their present dispersion at water depths not shallower than $-3 \mathrm{~m}$, imply that palaeo sea level at the time of the wreckage, was close to present level. 

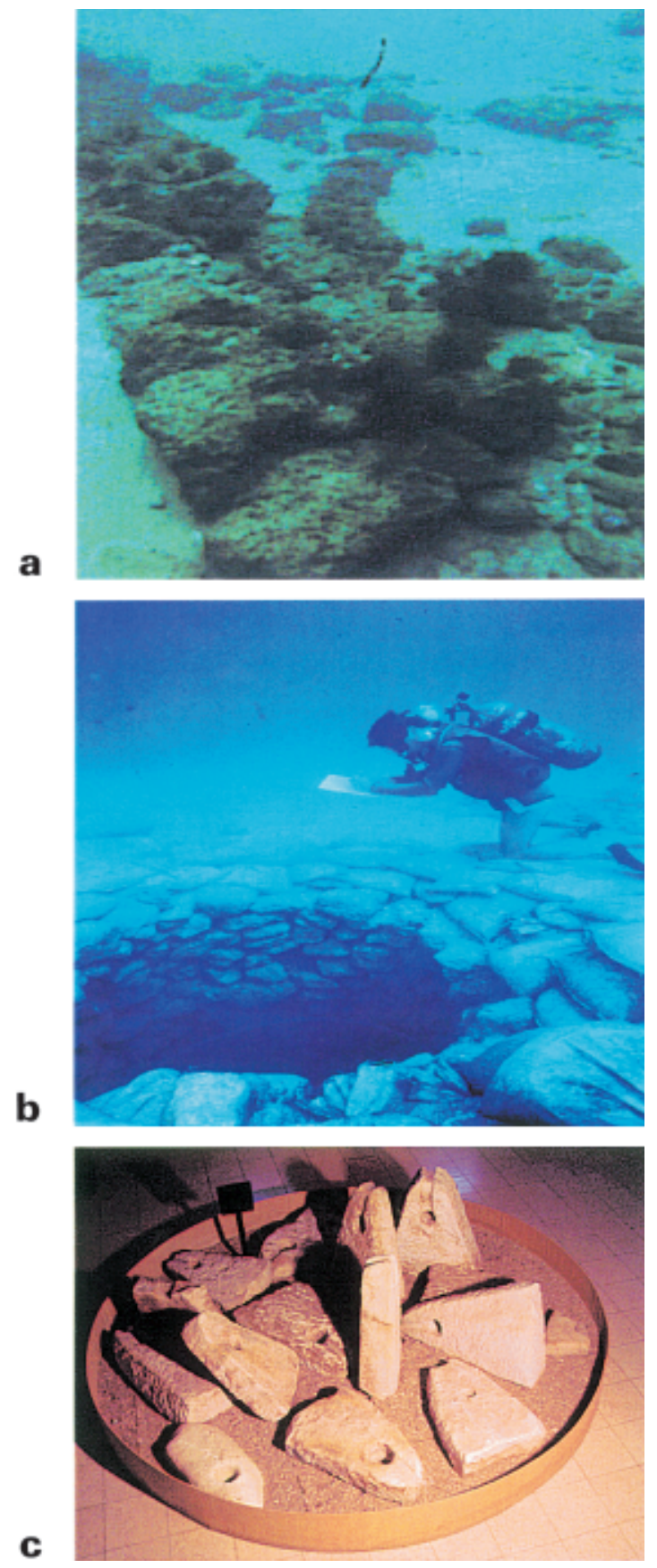

eustatic change. Much further away again, the departures from eustasy are controlled mainly by the unloading and loading of the seafloor as a result of water volume changes. This is the hydro-isostatic component.
The sea-level change in Israel and the surrounding region falls into this category (see below).

High-resolution numerical models that represent the spatial and temporal variability of sea-level change and shoreline evolution have been developed over recent years that give good representations of sea-level change in the Mediterranean region and which have been used to separate the tectonic contributions from the eustatic-isostatic factor (Lambeck, 1995, 1996a; Lambeck and Bard, 2000).

In this study, we compare predictions based on these models with the observed trends of sea level for the coast of Israel. This should determine whether the glacio-hydro-isostatic models are adequate for this region or whether other tectonic movements have been significant along this section of the Mediterranean coast. The working hypothesis is that the parameters defining the isostatic model for Israel are adequately determined by similar studies from other tectonically stable areas and that any significant discrepancies between predictions and observations reflect mainly the tectonic movement. The resulting estimates may contribute to the controversial issue of the vertical movement rates along the Israeli coast (Kafri, 1969, 1996; Kafri et al., 1983; Neev et al., 1987).

\section{Observations}

Most of the observations used in this analysis are from submerged archaeological sites, with a few land observations of mainly water-front man-made structures and wells located up to $100 \mathrm{~m}$ from the coastline. Underwater archaeological sites include living floors and wells associated with submerged settlements (Plate 1a and b), and assemblages of shipwrecks (Plate 1c). In these now submerged settlements underwater archaeologists have discovered paved floors, stone-wall foundations wooden fences

Plate 1. (a) Foundation walls at the underwater site of Atlit Yam provides an upper bound for palaeo sea level (photographed by E. Galili). (b) The submerged water well at Atlit-Yam with its top at $-10 \mathrm{~m}$ and its base at $-15.5 \mathrm{~m}$ provides upper and lower bounds on ancient sea-level (photographed by E. Galili). (c) Assemblage of stone anchors, Neve Yam. The present dispersion line of heavy objects from wreckage time represents palaeo sea level that was close to the present one. (photographed by E. Galili). 
and various installations such as hearths and pits that all identify an upper limit to sea-level at the time of their construction and habitation. Wells that are found today either below or above present sea level bear information about the palaeo-watertable at the time of their use and this provides an indirect measurement of the sea-level position. On land, numerous manmade installations are also indicative of sea-level change. These include relicts of anchorages, slipways, piscinas or rock-cut pools with drainage channels and quarried ponds (Flemming et al., 1978; Raban, 1981, 1995; Raban and Galili, 1985; Galili and Sharvit, 1998; Sivan and Galili, 1999). Although previous studies along the Israeli coast have used land archaeology finds for reconstructing sea-level curves in historical periods (Wreschner, 1983; Sneh and Klein, 1984; Raban and Galili, 1985; Galili et al., 1988; Galili and Nir, 1993), we exclude part of these indicators here because of dating inaccuracies. Dating by using cultural terms, like "Bronze Age" cover hundreds to thousands of years and thus treated in this research as not accurate enough. We use only underwater and land archaeological indicators for palaeo sea-level, dated by means of Carbon-14 (Table 1), or precise typology. All dates are uncalibrated, based on the existing radiocarbon chronology of the Levant (Gopher and Gophena, 1993; Gopher, 1993). For the Early Holocene (8150$6200 \mathrm{BP}$ ), all ages have been obtained by radiocarbon dating of relicts found in the underwater sites (Table 1). Thus, all observational data corresponding to radiocarbon years is consistent with the ice models and time constant of the Earth's response (Lambeck, 1998).

Table 2 summarizes the acceptable Late Holocene ages obtained by typological dating of underwater and lands sites. In places, the construction elements of land and underwater wells include wooden beams or organic contents that can be radiocarbon dated. In other cases, the base of the wells was paved with pottery sherds to prevent silting of the water, and these sherds provide the typological dating tool for the usage period of the well (Nir and Eldar, 1986, 1987). All observations used in this study are older than 2000 years.

\subsection{Underwater archaeological indicators}

The oldest underwater archaeological site on the Mediterranean shelf of Israel is the Atlit-Yam (Fig. 1 and Table 1). The site is a submerged Pre-Pottery Neolithic village covering an area of $40,000 \mathrm{~m}^{2}$ and located at a water depth of 8-12 m. Underwater archaeologists have found house foundations, straight walls, hearths, round installations and paved floors. The finds include charcoal and waterlogged plant remains (grains, branches and pollen), animal bones and human burials (Galili and Nir, 1993). The site is ascribed to the end of the Pre-Pottery Neolithic period (8140-7550 BP). Radiocarbon dates for charcoal from hearths gave $8140 \pm 120$ and $8000 \pm 90 \mathrm{BP}$ (Galili and Weinstein-Evron, 1985; Galili et al., 1988) consistent with the typological date. A submerged water well with its top at $-10 \mathrm{~m}$ and its base at $-15.5 \mathrm{~m}$ also provides a significant limiting value on the sea-level position at this time.

Late Pottery Neolithic ( $6600-7000$ BP) underwater sites occur along the Carmel coast, including Kefar Samir, Megadim Neve-Yam and Tel Hreiz (Fig. 1 and Table 1). The Kefar Samir site is located 10-200 $\mathrm{m}$ from the present coastline, at depths of $0.5-5.5 \mathrm{~m}$. The site contains paved floors and numerous $0.6-1 \mathrm{~m}$ diameter pits excavated in the submerged clay; some of which have been inlaid with undressed stone and others have been constructed of wood branches and stones. The pits contain soft clay, flint artifacts, potsherds and waterlogged and charcoal plant remains (olive stones, mat fragments and wooden bowls (Galili et al., 1989; Galili and Schick, 1990; Galili et al., 1997). One of the pits, with an opening located at $-5 \mathrm{~m}$, was excavated and cleaned to $-7 \mathrm{~m}$ without reaching the original bottom. The pit apparently served as a water-well; it is built of alternating courses of wooden branches and stone pebbles. Two wood samples give radiocarbon dates of $6830 \pm 60$ and $6830 \pm 80 \mathrm{BP}$ (Galili and Weinstein-Evron, 1985). A different set of samples, in water depths that differ from each by about $1 \mathrm{~m}$ (Table 1), were ${ }^{14} \mathrm{C}$ dated at 7540 and $7380 \mathrm{BP}$ (reported as $5540 \pm 370$ and $5380 \pm 310 \mathrm{BC}$ by Raban and Galili, 1985).

At the Megadim site (Fig. 1 and Table 1), $100 \mathrm{~m}$ offshore and at about $3.5 \mathrm{~m}$ below sea level, three pits located $50 \mathrm{~m}$ apart from each other were found. The southern pit was partly excavated and contained flint flakes, botanical remains and a predator mandible that has been ${ }^{14} \mathrm{C}$-dated as $6310 \pm 70 \mathrm{BP}$. A sample of organic clay taken from a depth of $10 \mathrm{~cm}$ near the 
pit, yielded a ${ }^{14} \mathrm{C}$ age of $7060 \pm 70 \mathrm{BP}$ (Galili and Weinstein-Evron, 1985). About 25 additional pits were found at various locations from Kefar Samir in the north to Neve-Yam in the south (Fig. 1). These pits are typologically dated as Late Pottery Neolithic (Galili and Weinstein-Evron, 1985).

A Late Pottery Neolithic site south of Atlit, at Neve-Yam (Fig. 1 and Table 1), extends from the present shoreline to a water depth of $5 \mathrm{~m}$. Evidence include rectangular houses, silos, storage pits and hearths, flint tools, stone artifacts, animal bones, plant remains, and pottery sherds, that were found in dark clay (Raban, 1983; Galili and Weinstein-Evron, 1985; Galili et al., 1988). Charcoal plant remains yielded a ${ }^{14} \mathrm{C}$ date of $6860 \pm 60 \mathrm{BP}$ (Wreschner, 1983). A cemetery with seven graves built of calcareous sandstone slabs that contain human skeletons has also been exposed. The ceramic material as the flint tools, are all characteristic of Late Pottery Neolithic period (Galili et al., 1998).

At the site of Tel Hreiz (Fig. 1 and Table 1), a wooden fence made of vertical branches was found at a water depth of $2.5 \mathrm{~m}$ (Galili et al., 1988). Some of the branches have been preserved up to $0.6-0.7 \mathrm{~m}$ above the surface of the sea-bottom (Raban and Galili, 1985) and have been dated as $6270 \pm 50{ }^{14} \mathrm{C}$ BP (Galili et al., 1988).

The submerged settlements from about 8100 to about $6300 \mathrm{BP}$ are always found embedded in dark clay. In contrast, shipwreck assemblages from historical times (from Middle and Late Bronze age to the Hellenistic period, $\sim 4000-2100{ }^{14} \mathrm{CBP}$ ) lie invariably above the clay layer. Along the Carmel coast, shipwreck assemblages usually occur at water depths of 5-3 m. (Galili et al., 1988). Further south, stone anchors of Late Bronze, Persian and Hellenistic ages have been found at Ashkelon (Galili and Sharvit, 1996; Sharvit and Galili, 1998;), Yavne-Yam (Raban and Galili, 1985; Galili and Sharvit, 1991, 2000; Galili et al., 1993) and Tel Ridan (in Gaza strip, unpublished data). At the southern as well as at the northern sites, the easternmost dispersion line of anchors and heavy objects originated from shipwreck occurs at a depth of $3 \mathrm{~m}$.

\subsection{Land archaeological indicators}

Along the Israeli coast, several wells older than
2000 years, have been dated using typological criteria (Table 2). The functioning period of the well is represented by pottery sherds, commonly found in a dark clay layer at the bottom of the well, since it was common practice to pave the bottom of the well with sherds in order to prevent the mixing of mud and drinking water. Along the Israeli coast, such wells occur in Tel Nami and Tel Dor in the north, Tel Michmoret in the central coast and Yavne Yam in the south (Fig. 1 and Table 2).

The Tel Nami site on the Carmel coast (Fig. 1 and Table 2) contains several well-dated indicators for sea level. Excavations revealed that the site was inhabited from Middle Bronze 2a (MB2a) to Late Bronze 2b (LB2b), dated to $4000-3750{ }^{14} \mathrm{C}$ BP. The principal indicator for ancient sea level is from the MB2a well, situated about $100 \mathrm{~m}$ inland from the coastline. This well is constructed of local sandstone and its lowest course lies at $-0.7 \mathrm{~m}$. The date of the well is inferred from MB2a pottery found in the dark clay layer at the bottom and in the sandy clay layers above that postdate the operation of this well (Marcus, 1991).

Tel Dor (Fig. 1 and Table 2) is one of the largest and richest Tels containing archaeological features that are indicative of palaeo sea-levels along the Israeli coast. Flushing channels in the northern bay, systems of feeding sea-water into the industrial area and slipways in the western part, are tools for reconstructing palaeo sea-levels, but most of them are not dated accurately enough. In the northern bay, there is a flushing channel, with its deepest bottom at $-1.6 \mathrm{~m}$ providing a lower bound for sea level, and a solution notch at $-0.2 \mathrm{~m}$ indicating an upper limit. The channel was dated to the Hellenistic period by sherds and lead net-weights that were found on the channel bottom. In the southern part of Tel Dor, the archaeological complex provides relatively better dated indicators of sea levels for the period around 3200$3000 \mathrm{BP}$. In this area, there are phases of pavements constructed of huge adjacent blocks (their original dimensions were as much as $4.5 \mathrm{~m}$ long by $1.5 \mathrm{~m}$ wide), running $\mathrm{E}-\mathrm{W}$ almost parallel to the present water-line, and which may have served as quays (Raban, 1995). One of the most ancient lines of blocks is dated to the end of the 13th century BC (about $3250 \mathrm{BP}$ ) and the base of its best preserved block lies at $-0.4 \mathrm{~m}$. Another pavement that probably functioned 
as a quay is dated to around $1200 \mathrm{BC}$ (about $3200 \mathrm{BP}$ ), Its regular flat slabs with their shorter sides facing the sea front. The base of this pavement is also at $-0.4 \mathrm{~m}$. The best evidence for palaeo sea levels from Tel Dor occurs from a well whose quarried bedrock is at $-0.42 \mathrm{~m}$. Three phases of well construction have been identified, each one higher by two courses of stone work, with each stage surrounded by a floor at levels of $+1.04,+1.57$ and $+2.43 \mathrm{~m}$, indicating human response to rising sea level. The few sherds that were found on the floor of the first phase were dated to the late 13th century BC (about $3200 \mathrm{BP}$ ) whereas the pottery assemblage of the third phase is of the 11th century BC (about $3100 \mathrm{BP})$.

At Michmoret, located in the central coast of Israel (Fig. 1 and Table 2), a well was excavated $25 \mathrm{~m}$ inland from the present coast. The bottom of the well is at $-1.4 \mathrm{~m}$ and contains clay and sand mixed with Persian and Hellenistic ( 2600-2100 BP) pot sherds (Nir and Eldar, 1986). Another ancient well was excavated at a site approximately $25 \mathrm{~m}$ inland in Yavne Yam (Fig. 1 and Table 2). The bottom of this well is at $-0.7 \mathrm{~m}$ and the lower layer contains clay with many Hellenistic pottery sherds (Nir and Eldar, 1986).

\section{The archaeologically determined constraints on sea level}

Three criteria have been used here to bracket the palaeo sea levels at different time periods for the last 8000 years:

1. Coastal water-front man-made structures and habitation surfaces of underwater sites provide both upper and lower constraints. On land, man-made structures that can be directly related to sea-level position, such as the flushing channels and slipways of Tel Dor, give a relatively accurate indication of palaeo sea level. Living floors of underwater sites provide upper bounds only and under the assumption that the living quarters were above the sea spray level (Galili et al., 1988), the sealevel is assumed to have stood at least $2 \mathrm{~m}$ below these floor levels (Fig. 2a and Plate 1a).

2. Ancient wells, both from underwater and on-land coastal sites, provide upper and lower bounds on sea-level (Galili and Nir, 1993). The present watertable in wells up to $150 \mathrm{~m}$ inland along the Israel's coastline is at 0 to +0.5 m elevation. Coastal wells have to be dug to a minimal depth in order to avoid salinization but they still have to be effective at the lowest water level corresponding to either seasonal low levels or to extreme low tides. Archaeologists assume that at least $30-40 \mathrm{~cm}$ of water depth was needed in ancient times to draw clear water from the well when using jars. Thus, the inferred depth for all ancient coastal water wells is $0.3-0.4 \mathrm{~m}$ below the watertable, which implies that the upper limit of the well base was about $0.1-0.2 \mathrm{~m}$ above mean sea-level at the usage period of the well. For a lower bound we adopt a level of $1 \mathrm{~m}$ below sea level (Fig. 2b and Plate 1b).

3. Wreckage assemblages now scattered on the shallow shelf provide a relatively reliable estimate of palaeo sea level. Observations of recent shipwrecks show that heavy objects, such as cargo, anchors, etc. are scattered in the surf zone in very shallow water close to the coastline. Thus, the dispersion line of the heavy objects from shipwrecks represents more or less the palaeo-coastline. The ancient shipwrecks have been preserved because they were covered by sand soon after they were wrecked, while heavy objects sink through the sandy layer until they reach harder clay or rock substrata. Like the situation today, we assume that approximately $1.5-2 \mathrm{~m}$ of sand covered these objects at the time of wreckage (Galili et al., 1988), and the presence of stone anchors of Late Bronze to Hellenistic period at water depths not shallower than $-3 \mathrm{~m}$ imply that sea level during this period was close to the present one. Thus, sea level from Late Bronze age on can be reconstructed to $-1 \mathrm{~m}$ up to the present level, but cannot be lower than $-3 \mathrm{~m}$. Shipwrecks of Late Bronze to Hellenistic age occur at the same water depths along the northern and southern Israeli coast, and therefore are indicative of similar sea-level fluctuations along the entire coast (Fig. 2c and Plate 1c).

Fig. 3 summarizes the data from Tables 1 and 2. Upper and lower limits are indicated. The evidence points to a rapid rise in sea level between about 8000 and $6000 \mathrm{yr} \mathrm{BP}$ and a much-reduced rate for the period 4000-2000 yr BP. The absence of evidence 


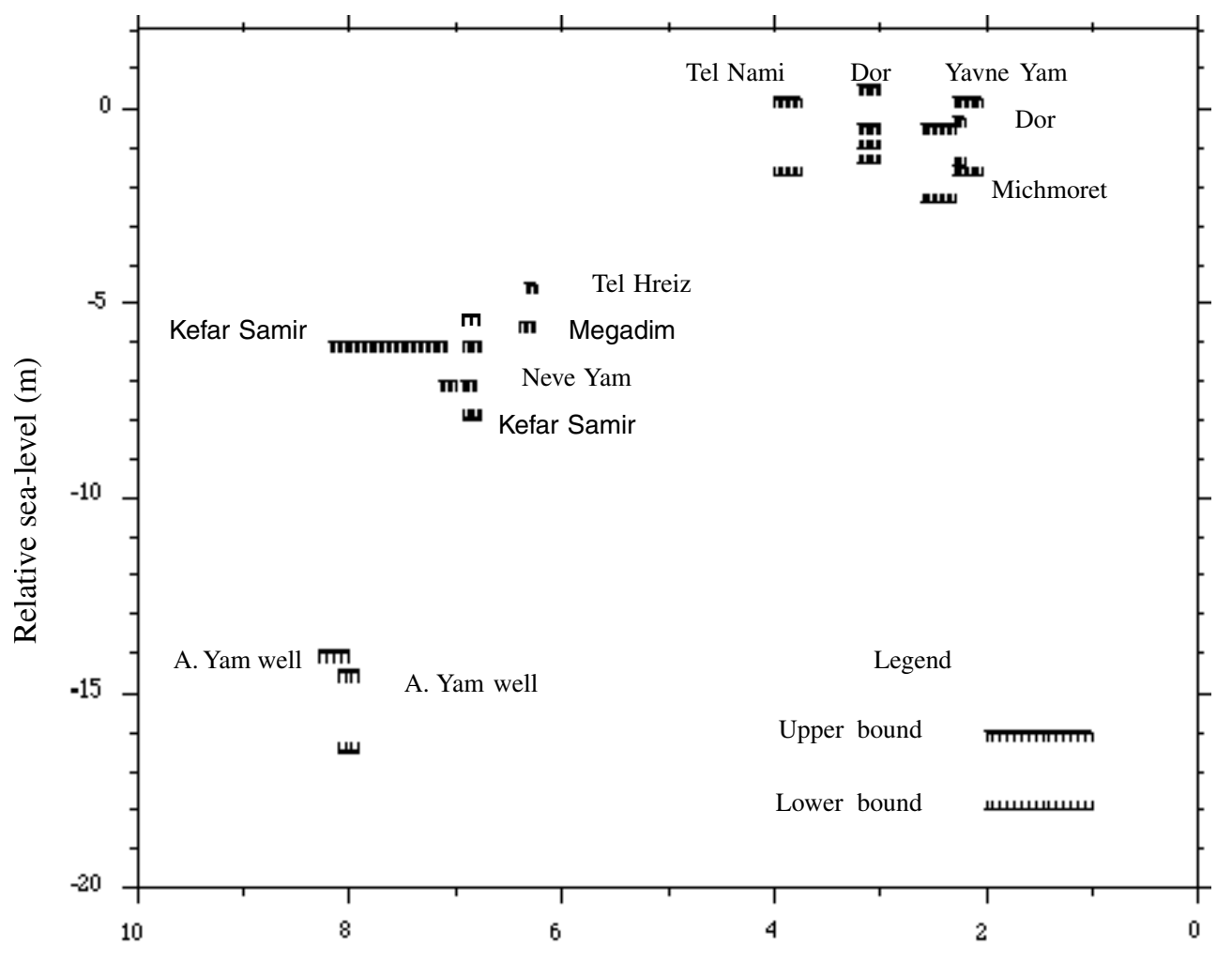

Time $\left(\mathrm{X} 1000{ }^{14}\right.$ C years BP)

Fig. 3. Underwater archaeological constrains of palaeo sea level for the Mediterranean coast of Israel. Upper and Lower limits are indicated.

between 6000 and 4000 years prevents an assessment to be made on the timing of the change in rate and new data for this interval would be most desirable.

\section{Predicted sea-level change}

The main causes for relative sea-level change during the Holocene are: (i) the increasing ocean volume resulting from the late melting stages of the ice sheets and the concomitant isostatic adjustments of the crust; the glacio-hydro-isostatic effects; and (ii) vertical tectonic movements of the crust of a nonglacio-hydro-isostatic nature. The former can be modeled with high resolution and can be tested against observations of sea-level change from tectonically stable regions around the world. Parameters constraining the model-mantle rheology and ice sheet can be estimated from this analysis and the result is a predicted model of the spatial and temporal variability of sea-level change around the world. The mathematical model used here has been described in Nakada and Lambeck (1987) and Johnston (1993) with subsequent refinements by Drs P. Johnston and G. Kaufmann at ANU. The predictions have been extensively tested for different regions around the world and the resulting earth-model and ice-models parameters yield consistent agreement between models and observations (Nakada and Lambeck, 1988; Lambeck and Nakada, 1990; Lambeck, 1996a,b; Lambeck et al., 1996, 1998). These models appear to be sufficiently robust that when applied to regions of tectonic activity, they permit a separation to be made of tectonic and isostatic contributions to relative sea-level change (Lambeck, 1995).

One assumption made in these models is that the 
Table 3

Earth model parameters for a three-layer mantle model. E0 is the preferred model and models E1 to E6 represent the range of parameters that are broadly consistent with observed sea-level change across northern and western Europe. $H_{1}$ is the effective lithospheric thickness, $\eta_{\text {um }}$ is the effective upper-mantle viscosity and $\eta_{1 \mathrm{~m}}$ is the effective lower-mantle viscosity

\begin{tabular}{lcll}
\hline Model & $H_{1}(\mathrm{~km})$ & $\eta_{\text {um }}(\mathrm{Pa} \mathrm{s})$ & $\eta_{\text {lm }}(\mathrm{Pa} \mathrm{s})$ \\
\hline E0 & 65 & $4 \times 10^{20}$ & $10^{22}$ \\
E1 & 50 & $4 \times 10^{20}$ & $10^{22}$ \\
E2 & 100 & $4 \times 10^{20}$ & $10^{22}$ \\
E3 & 65 & $3 \times 10^{20}$ & $10^{22}$ \\
E4 & 65 & $5 \times 10^{20}$ & $10^{22}$ \\
E5 & 65 & $4 \times 10^{20}$ & $5 \times 10^{21}$ \\
E6 & 65 & $4 \times 10^{20}$ & $5 \times 10^{22}$ \\
\hline
\end{tabular}

Earth's response is spherically symmetric whereas lateral rheological structure is known to occur in the mantle. Such variations, however, appear to be unimportant in the rebound modeling because of trade-off that occur in the response function between effective lithospheric thickness and effective upper-mantle viscosity (Lambeck, 1995; Lambeck et al., 1996). The mantle parameters used here for these two layers, as well as for the lower mantle viscosity, found to give a good representation of the isostatic response, are summarized in Table 3.

The ice models used include contributions from Fennoscandia, the Barents Sea, Laurentia and Antarctica. Their combined ice volume and equivalent sealevel function corresponds to that given by Fleming et al. (1998). It includes a small increase in ocean volume for the past 6000 years due to residual melting of distant ice sheets, possibly from Antarctica or possibly from temperate mountain glaciers (Nakada and Lambeck, 1988), such that sea-level have risen globally by $3 \mathrm{~m}$ since that time. Analysis of Holocene sea level from other tectonically stable regions indicate the need for such a contribution (e.g. Fleming et al., 1998; Lambeck et al., 1996, 1998).

The isostatic model includes the contribution arising from the changing ocean volumes as the ice sheets melt, the effect of the changing shape of the ocean basin as the sea floor deforms in response to the surface loading, the time dependence of shorelines as sea-level changes, and the changing surface area occupied by ice sheets that are grounded in shallow water.

For the eastern Mediterranean, the isostatic contributions to the sea-level change in Holocene time are the competing effects of the glacio and hydro-isostatic factors. Here, the first results in a slowly rising sea level in Late Holocene time due primary to the crustal subsidence as mantle material flows back beneath the formally glaciated region of Scandinavia. The hydroisostatic contribution is one of falling sea level along the Israeli coast in response to the loading of the Mediterranean by the meltwater and the flow of material from beneath the oceanic lithosphere to beneath the continental lithosphere (cf. Lambeck, 1996a,b, for analogous results in the Aegean and Persian Gulf regions).

Fig. 4a illustrates the predicted sea-level for a coastal site near Tel Aviv that is representative of the coastal zone as a whole. In this preliminary result all melting is assumed to have been completed by 6000 years and the small highstand of about $1 \mathrm{~m}$ indicates that the hydro-isostatic term at this time dominates over the glacio-isostatic contribution. Fig. 4b, curve 1, illustrates the nominal equivalent sea-level function adopted, along with the function proposed by Fleming et al. (1998) in which ocean volumes

Fig. 4. Predicted sea levels based on different model assumptions. (a) At a coastal location near Tel Aviv for the nominal earth model E0, Scandinavian ice model SCAN-2 and nominal North American and Antarctic ice models, and the nominal equivalent sea-level (esl) function (curve 1 in (b)). The inset illustrates the mid-Holocene highstand on an expanded scale. (b) The nominal equivalent ice function (esl) (curve 1) and the modified function (curve 2) after Fleming et al. (1998). (The esl represents the globally averaged change in sea level that is a consequence of the change in the shelf-grounded and land-based ice sheets.) (c) The predicted sea level at Tel Aviv for the same earthand ice-model parameters as in (a) but with the modified esl function of (b). (d) Earth model dependence for the same site and ice sheet conditions as in (a) for the six earth models identified in Table 3. The major dependence occurs for the lower mantle viscosity (curves E5 and E6 in the inset, corresponding to the same-named models in Table 3). (e) The Scandinavian ice model dependence of the predictions for the same conditions for other variables as in (a). Ice models SCAN-1 and SCAN-2 differ in their distribution of ice within the Scandinavian ice sheet whereas SCAN-2 contains about 50\% more ice than the other two models (see Lambeck et al. 1998). (f) The predicted sea level for Tel Aviv (solid line) for the same sites as (a) with the upper and lower limits (dashed lines) based on the uncertainties introduced from the earth- and icemodel parameters and the esl function. 

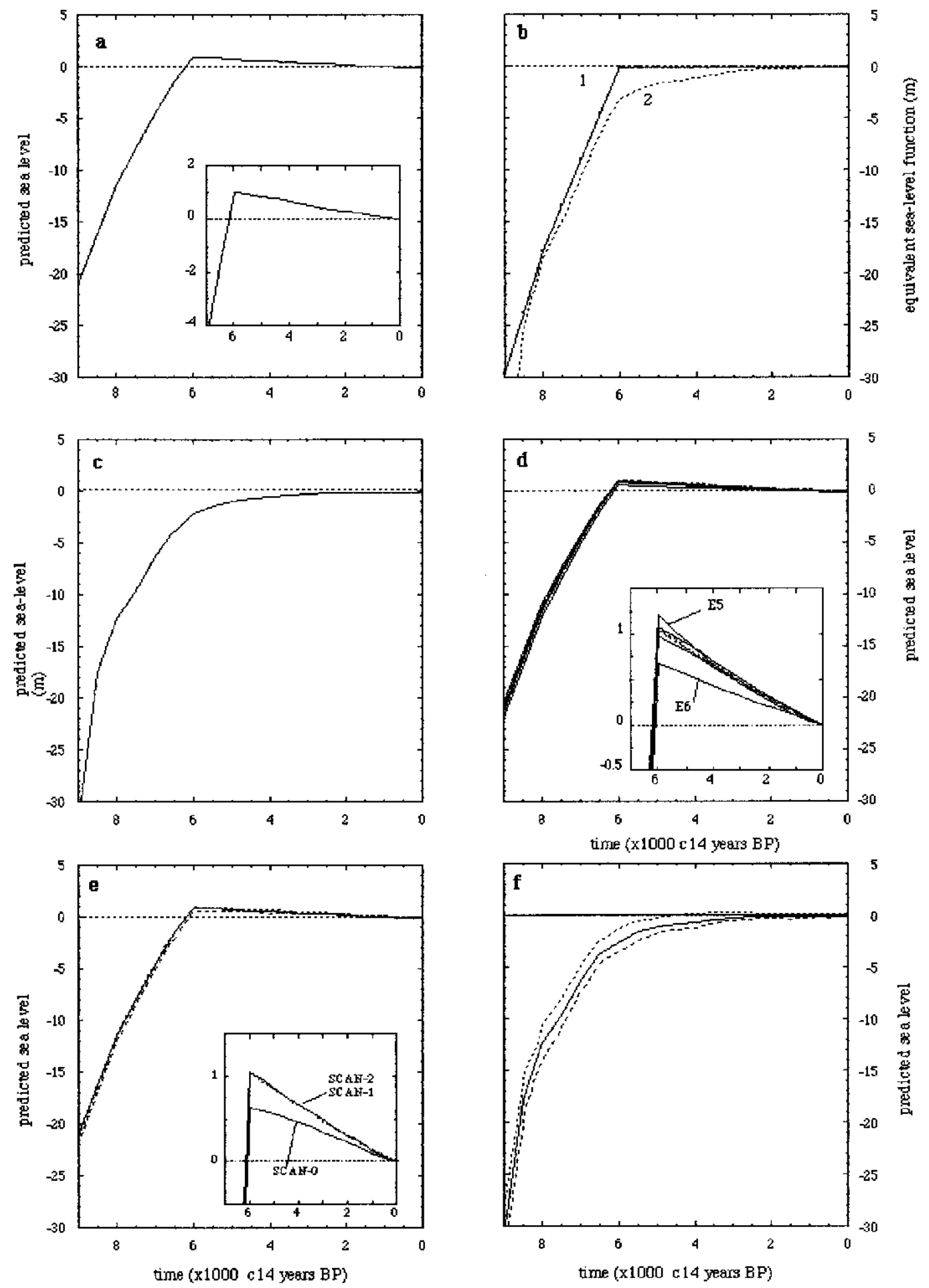
continue to increase into more recent times (curve 2). Now the predicted sea level is one of a slowly rising level throughout the past 6000 years (Fig. 4c); the small increase in ocean volume being largely sufficient to negate the hydro-isostatic contribution.

The above predictions are based on the nominal earth model E0 defined in Table 3 and the nominal melting model with zero melting over the last 6000 years. The consequence of uncertainties in these parameters is illustrated in Fig. 4d in which the range of earth-models encompass the uncertainties in the three mantle parameters (see Table 3). Within this range of parameters, predictions for the Holocene differ by amounts that are less than the observational accuracies and the model E0 can be considered to yield representative results. Of note is that the greatest uncertainty comes from the choice of lower mantle viscosity with the models E5 and E6 showing the greatest departure from the nominal model E0 (Fig. 4d). This is consistent with other studies for the Mediterranean (Lambeck and Bard, 2000; Lambeck, 1995) that indicate that high accuracy sea-level data from these regions may lead to improved constraints on this least-well determined parameter of the earth-rheology model. Some uncertainty in the predictions may also arise from the choice of ice models. The Scandinavian ice model is most significant for this region and the adopted model (SCAN-2) is one in which the ice was relatively thin over the southern and southeastern areas during the late glacial stages (Lambeck et al., 1998). The comparison with a steeply-domed ice model (SCAN-1), with a similar ice volume to SCAN-2, but in which the ice thickness is distributed more symmetrically between the western and the eastern regions, indicate that the details of the distant ice sheets are not important provided that the ice volumes, constrained by the equivalent sea-level function are approximately correct. For a much larger ice, Scandinavian ice sheet (SCAN-0), steeply domed and with a maximum ice thickness in excess of $3000 \mathrm{~m}$ and a volume that is $50 \%$ greater than that of SCAN-1, the amplitude of the highstand is reduced because the negative glacioisostatic contribution is magnified but the consequence for the Israel predictions remains small (Fig. 4e). Fig. 4f illustrates the predicted sea level at the Tel Aviv locality based on the complete model based on the earth-parameters E0, the SCAN-2 ice model and associated North American and Antarctic ice models (see Lambeck et al. 1998), and the equivalent sealevel function of Fleming et al. (1998). The upper and lower estimates of the predicted values are based on the square root of the sum of the squares of the uncertainties from: (i) the earth-model parameters; (ii) the Scandinavian ice sheet; and (iii) the equivalent sea-level function. For the interval for which observational evidence is available the range of predictions at any time step does not exceed $3 \mathrm{~m}$ and is of a similar magnitude or smaller than the observational uncertainties of much of the data.

Some variation in sea-level is predicted to occur along the $150 \mathrm{~km}$ sector of coastline covered by the observational evidence, as is illustrated in Fig. 5a and $\mathrm{b}$ for four localities, Haifa (curve 1), Michmoret (curve 2), Tel Aviv (curve 3) and Tel Ridan (curve 4) (see Fig. 1 for locations). This spatial variability is, however, mostly less than the observational uncertainties and data from different coastal locations can be combined into a single sea-level curve without introducing uncertainties that are greater than the other prediction and observation errors. Only if a high density of high-accuracy observation points were available from the different sections of the coast, would it be constructive to consider separate sea-level curves for, for example, the Carmel or Central coasts. The predicted variation in the sea-level signal for a section orthogonal to the coastline through the site of Dor is illustrated in Fig. 5c. Curve 2 is for the coastal site, curve 1 is for a site $10 \mathrm{~km}$ inland and sites 3 and 4 are 10 and $20 \mathrm{~km}$ offshore, respectively. All observational data sites lie well within this distance range of the present shore line and this spatial variability is also small over the distance at which evidence of sea-level change is currently available. Thus, for present purposes, data from localities at different distances from the present shoreline can also be combined into a single sea-level curve that will be representative of that part of the Israel coast under consideration here to within the level of observation and prediction uncertainties.

\section{Discussion}

\subsection{Sea-level variations - observations versus predictions}

Most of the observational evidence for sea-level 

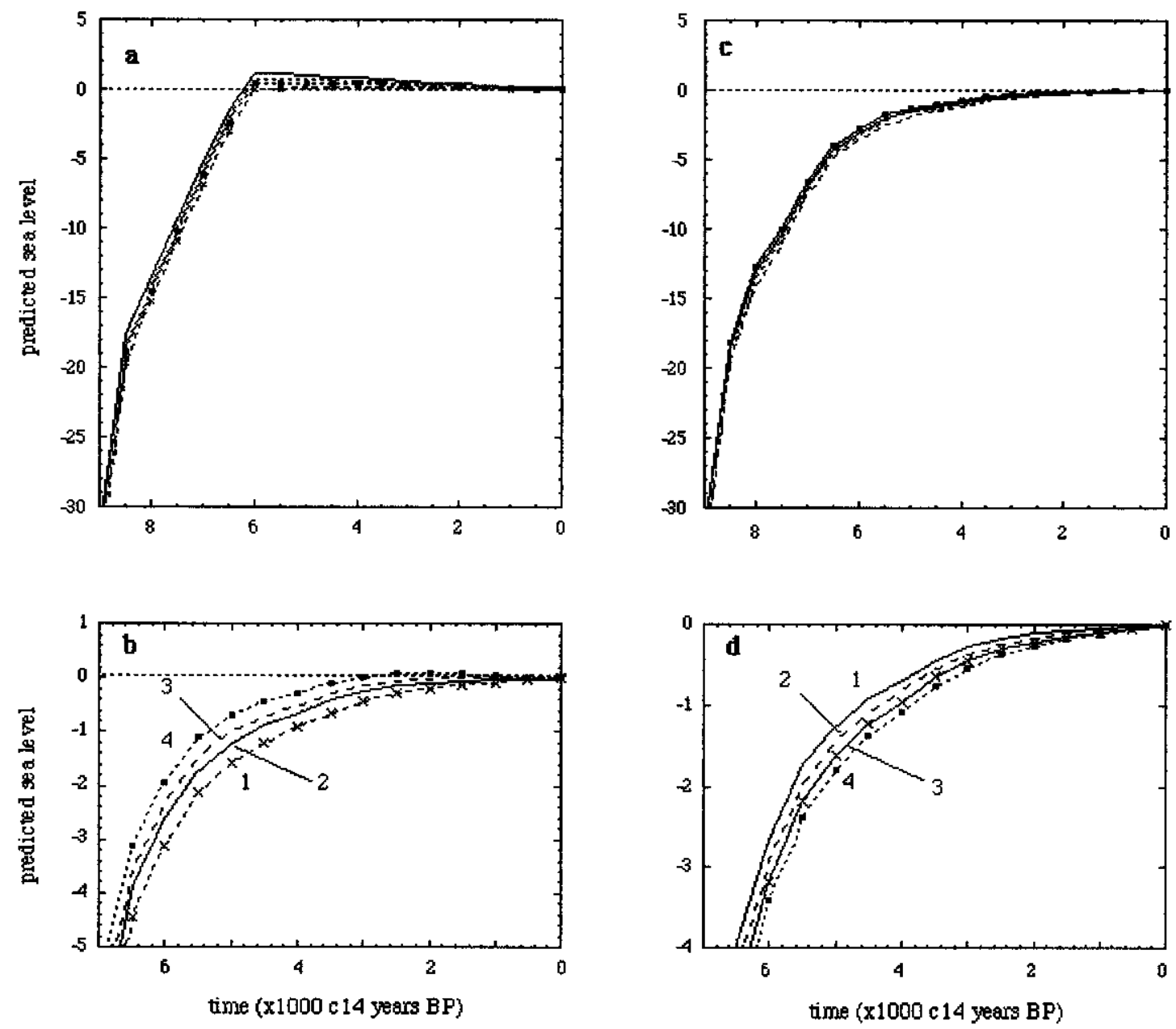

Fig. 5. Predicted sea levels for different locations along the Israel coast. Curve 1, Haifa; curve 2, Michmoret; curve 3, Tel Aviv; curve 4, Tel Ridan (see Fig. 1b for locations). (a) The same model parameters as in Fig. 4a. (b) The Late Holocene part of the record on an expanded scale and for the parameters corresponding to the equivalent sea-level function of Fleming et al. (1998) (curve 2 Fig. 4a). (c) and (d) Predicted sea levels along a section orthogonal to the coast through Dor on the Carmel coast. Curve 3 (d) corresponds to the coastal location; curves 1 and 2 correspond to locations 20 and $10 \mathrm{~km}$ offshore, respectively, and curve 4 corresponds to a site $10 \mathrm{~km}$ inland. Predictions are for the same equivalent sea-level function as in (b).

change comes from the Carmel coast (Fig. 1) and the predicted levels for this locality are illustrated in Fig. 6. These are based on the same preferred model parameters as used in Fig. $4 \mathrm{f}$ and the error estimates are based on the model uncertainties to which have been added the contribution from the small spatial variability that is predicted (Fig. $4 \mathrm{a}$ and $\mathrm{b}$ ) between the observation sites. The observed estimates of sea level are also indicated and where the observations permit both upper and lower limits to be inferred from the field evidence, the mean value has been adopted and the associated error bars correspond to the limiting values. The typical magnitude of the observational accuracies is about $\pm 2 \mathrm{~m}$ (Lambeck, 1997). Agreement between the observed and the predicted estimates is broadly satisfactory and any discrepancies generally lie within the combined uncertainties of the observations and predictions. Our model predictions for $8000 \mathrm{BP}$ indicate that sea level was at about $-13.5 \pm 2 \mathrm{~m}$ whereas the observed 


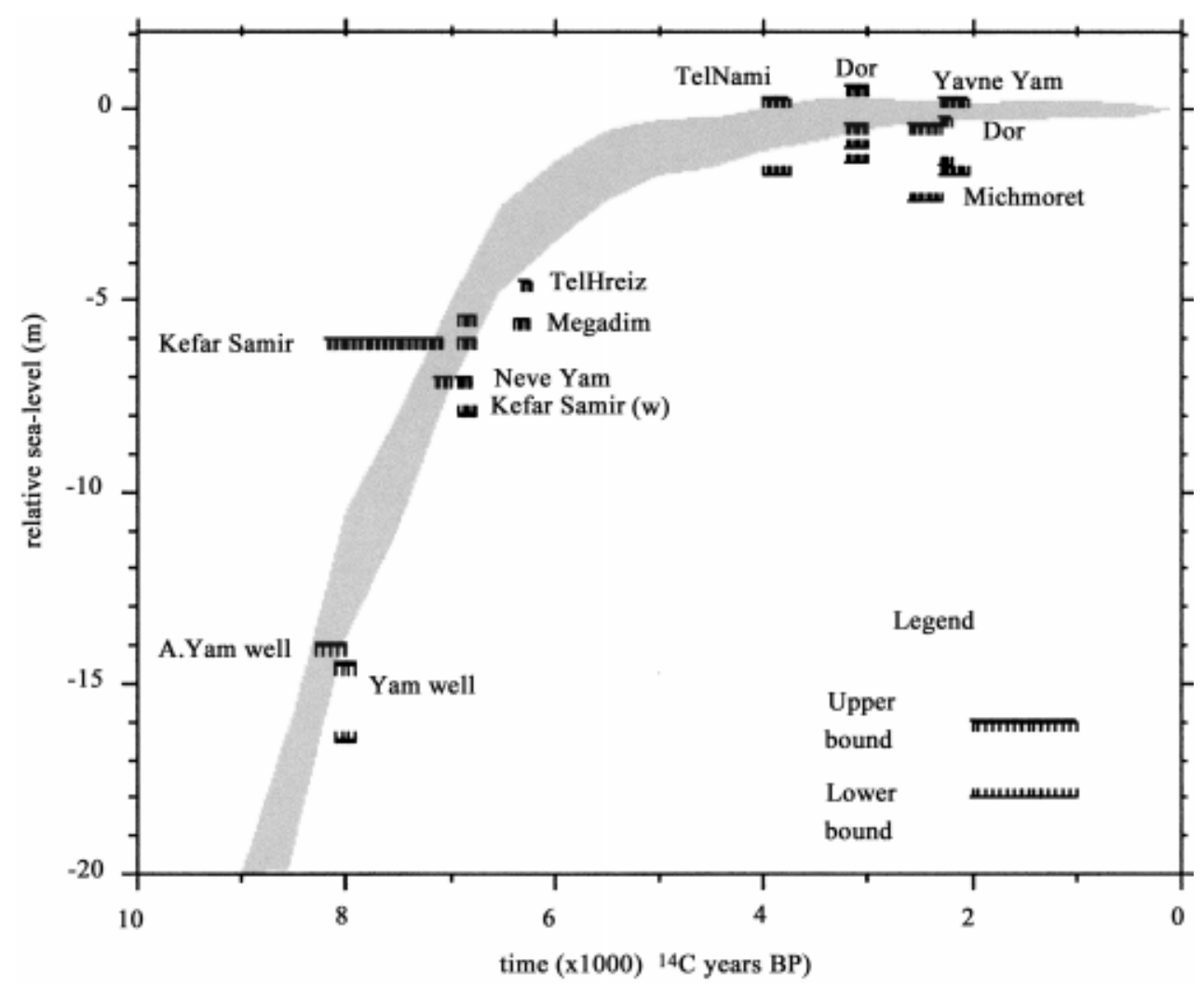

Fig. 6. Upper and lower limits of sea-level change predicted for the Carmel coast of northern Israel based on the same parameters as used to construct the Tel Aviv result in Fig. 4f. Observational data points are shown. Open circles with two-sided error bars correspond to the mean and range where upper and lower limits have been established. The solid circles without vertical error bars correspond to upper limits only. The time scale is in radiocarbon years.

from Atlit Yam place it at $-16.5 \pm 1 \mathrm{~m}$ and the difference is not significant. By $7000 \mathrm{BP}$ the predicted level has risen to about $-7 \pm 1 \mathrm{~m}$, consistent with the archaeological evidence from Megadim, Kefar Samir and Neve Yam, although the upper limit estimates from Kefar Samir indicate that the pits were well above sea-level at the time of their construction. The two upper limit estimates from Tel Hreiz and Megadim at about 6300 BP lie at the lower limit of the predicted value. Possibly the predicted level at this epoch is too high and, within the framework of zero tectonics, it may reflect an underestimation of the volume of the ice melting since about this time, as is suggested by some regional analysis of sea-level for the Late Holocene period (e.g. Lambeck, 1997). Alternatively, the wooden fence at $-2.5 \mathrm{~m}$ was closer to sea-level at the time of its construction than assumed (Table 1).

The evidence from Tel Nami at 4000 BP is consistent with model predictions of levels at 1-2 m below present, and indicates that the initially quit (typo) rapid rise in sea level slowed down between about 6000 and 4000 BP. More observational evidence for this interval is, however, clearly desirable. After $4000 \mathrm{BP}$ agreement between observations and predictions is also satisfactory with both showing no evidence for levels having been above present ones during this interval and with only a slowly rising sea-level during the Late Bronze to Iron ages (late 13th to 11th century BC). This later trend is consistent with the evidence at Tel Dor of the repeated renewal and higher elevation of successive wells and associated floors during this interval. Both predictions and observations for the 
Hellenistic period at 2400-2000 BP (from Tel Dor and Yavne Yam) indicate that present sea levels were reached by this time.

\subsection{Vertical crustal movements}

The broad agreement between the observations and predictions for the Israeli coast is similar to that obtained for most other localities in the Mediterranean and elsewhere and, without further and higher accuracy observational results, any discrepancies probably do not warrant special interpretations. Thus, within the modeling and observational accuracies, the comparison indicates that local vertical tectonic movements have not been significant in this region or, if they have, they have not led to a systematic displacement of the land relative to the sea over the last 8000 years. In the interval 8000-6000 BP the observed sea-level values tend to lie near the lower limit of the predictions and, if significant, this would place an upper limit to tectonic subsidence of about $\pm 0.2 \mathrm{~mm} /$ year.

The above estimate of subsidence can be tested against the position of the shoreline during the last interglacial, the marine oxygen isotope 5e (OIS 5e). Away from areas of former glaciation, this shoreline is usually found at a few meters above present sea-level, consistent with models of hydro-isostasy in which ice volumes during the preceding glacial stage 6 were similar to those of the Last Glacial Maximum. Along the Israel coast, the Yasaf member in the Galilee (Sivan, 1996; Sivan et al., 1999) and the Herzeliya member in the central and southern coastal plain (Gvirtzman et al., 1984) serve as chrono-stratigraphic markers of the OIS 5e. The base of this unit, a shallow marine sediment deposited on a relatively regular topography, does occur at different altitudes being 0 to $+5 \mathrm{~m}$ along the Galilee coastal plain (Sivan, 1996), $-12 \mathrm{~m}$ at the Carmel coastal plain (Michelson, 1970), and $-90 \mathrm{~m}$ in the central coast (Gvirtzman et al., 1984). Because the units are believed to have formed in water depths of not more than $30 \mathrm{~m}$ (Reiss and Issar, 1961), this is indicative of some differential tectonic behavior of different sections of the Israel coast. Thus the Carmel coastal plain has experienced little vertical tectonic movement since OIS 5e, consistent with the evidence for the past 8000 years, whereas the evidence for the central coast, suggests a minimum subsidence of about $60 \mathrm{~m}$ since OIS $5 \mathrm{e}$, at a minimum rate of about $0.5 \mathrm{~mm} / \mathrm{year}$. The one Late Holocene observation from this section of coast, from Yavne-Yam, occurs at about $2 \mathrm{ka}$ and the expected tectonic subsidence would be about $1 \mathrm{~m}$ or more but less than the observational accuracy. More Holocene evidence from this part of the coast is clearly!

\section{Conclusions}

The main conclusions of this study are:

1. The archaeological observations and the model predictions for Holocene sea-level change along the Mediterranean coast of Israel are generally consistent. The comparison indicates that at 8000 years ago sea level was not higher than -13.5 to $-16.5 \mathrm{~m}$. By $7000 \mathrm{BP}$, sea level had risen but still was not higher than about -7 . According to both the archaeological observations and the model predictions sea level was still lower than -3 to $-4.5 \mathrm{~m}$ at $6000 \mathrm{BP}$ and remained below its present level until about 3000-2000 BP. High frequency sea-level fluctuations during the last 4000 years were relatively minor, fluctuating by less than $1 \mathrm{~m}$.

2. By comparing the model sea-level curve to the archaeological observations, we are able to establish some constraint on the local tectonic contribution to the palaeo sea-level rise. Thus, we show that the average rate of vertical tectonic movement in the Carmel coast for the last 8000 years has been less than $0.2 \mathrm{~mm} /$ year. This is consistent with the geologically determined rate of $0.1 \mathrm{~mm} / \mathrm{year}$, in this area, for the last 120,000 years. Thus, the three lines of evidence - mathematical modeling, archaeological constraints and geological data - indicate that the principal factors influencing Holocene sealevel variations along the Mediterranean coast of Israel are eustatic and associated glacio-hydroisostatic effect. Vertical tectonic movements in this area acted at much lower rates and their influence on local Holocene sea level is insignificant.

\section{Acknowledgements}

We thank the National Center for Cooperation between Science and Archaeology, Weizmann Institute 
of Science, Rehovot Israel, for awarding the research fund, the results of which are presented in this paper. Thanks are also due to J.K.Hall for providing the DTM of the Mediterranean coast of Israel and to S. Ben-Yehuda, Marine Archaeology branch, Israel Antiquities Authority, for the drawings.

\section{References}

Fleming, K., Johnston, P., Zwartz, D., Yokoyama, Y., Lambeck, K., Chappell, J., 1998. Refining the eustatic sea-level curve since the Last Glacial Maximum using far- and intermediate-field sites. Earth Planet. Sci. Lett. 163, 327-342.

Flemming, N.A., Raban, A., Goetschel, C., 1978. Tectonic and eustatic changes on the Mediterranean Coast of Israel in the last 9000 years, In: Gamble, J.C., Yorke, R.A. (Eds.), Progress in Underwater Science. vol. 3 (New Series) of the report of the Underwater Association. Proceedings of the 11th Symposium at the British Museum (Natural History, 18-19th March, 1977, pp. 33-93.

Galili, E., Nir, Y., 1993. The submerged Pre-Pottery Neolithic water well of Atlit-Yam, Northern Israel, and its paleoenvironmental implications. The Holocene 3 (3), 265-270.

Galili, E., Schick, T., 1990. Basketry and a Wooden Bowl from the Pottery Neolithic submerged site of Kefar Samir. Mitekufat Haeven 23, 142.

Galili, E., Sharvit, J., 1991. Yavneh-Yam anchorage, finds from the underwater survey. In: Fisher, M. (Ed.), Yavneh-Yam and its surroundings, Kibutz Palmahim and Ariel, pp. 111-121 (in Hebrew).

Galili, E., Sharvit, J., 1996. Ashkelon north - underwater and coastal survey. Hadashot Arkheologiyot (English Edition) 106, 155 (Excavations and surveys in Israel, 18).

Galili E., Sharvit, J., 1998. Ancient coastal installations and the tectonic stability of the Israeli coast in historical times. In: Stewart, I.S., Vita-Finzi, C. (Eds.), Coastal Tectonics. Geological Society, London, Special Publication, 146, pp. 147-163.

Galili, E., Sharvit, J., 2000. Tel Ashkaelon - underwater and coastal survey. Hadashot Arkheologiyot (English Edition) (Excavations and surveys in Israel).

Galili, E., Weinstein-Evron, M., 1985. Prehistory and Palaeoenvironments of submerged sites along the Carmel Coast of Israel. Paleorient 11 (1), 37-51.

Galili, E., Weinstein-Evron, M., Ronen, A., 1988. Holocene sealevel changes based on submerged archaeological sites off the Northern Carmel Coast in Israel. Quat. Res. 29, 36-42.

Galili, E., Weinstein-Evron, M., Zohary, D., 1989. Appearence of olives in submerged Neolithic sites along the Carmel coast. Mitekufat Haeven 22, 95.

Galili, E., Dahari, U., Sharvit, J., 1993. Underwater surveys and rescue excavations along the Israeli coast. Int. J. Nautical Archaeol. 22 (1), 61-77.

Galili, E., Stanley, D.J., Sharvit, J., Weinstein-Evron, M., 1997. Evidence for earliest olive-oil production in submerged settle- ments off the Carmel coast, Israel. J. Archaeol. Sci. 24, 11411150.

Galili, E., Sharvit, J., Nagar, A., 1998. Neve Yam: underwater Survey. Hadashot Arkheologiyot (English Edition) 111, 8385 (Excavations and surveys in Israel).

Gopher, A., 1993. Sixth-Fifth Millennia B.C. Settlements in the coastal plain, Israel. Paleorient 19 (1), 55-63.

Gopher, A., Gophena, R., 1993. Cultures of Eighth and Seventh Millennia B.P. in the Southern Levant: a Review for the 1990s. J. World Prehistory 7 (3), 297-353.

Gvirtzman, G., Schachnai, E., Bakler, N., Illani, S., 1984. Stratigraphy of the Kurkar group (Quaternary) of the coastal plain of Israel. Geol. Surv. Isr., Curr. Res., 70-82.

Johnston, P., 1993. The effect of spatially non-uniform water loads on prediction of sea-level change. Geophys. J. Int. 114, 615-634.

Kafri, U., 1969. Recent crustal movements in Northern Israel. Isr. J. Geophys. Res. 74, 4246-4258.

Kafri, U., 1996. Sense and amount of vertical displacements related to the two main young tectonic phases in the lower Galilee. Geol. Surv. Isr., Curr. Res. 10, 81-83.

Kafri, U., Kaufman, A., Magaritz, M., 1983. The rate of Pleistocene subsidence and sedimentation in the Hula Basin as compared with those of other time spans in other Israeli tectonic regions. Earth Planet. Sci. Lett. 65, 126-132.

Lambeck, K., 1995. Late Pleistocene and Holocene sea-level changes in Greece and South-Western Turkey: a separation of eustatic, isostatic and tectonic contribution. Geophys. J. Int. 122, 1022-1044.

Lambeck, K., 1996a. Sea-level changes and shore-line evolution in Aegean Greece since Upper Paleolithic time. Antiquity 70, 588-611.

Lambeck, K., 1996b. Shoreline reconstructions for the Persian Gulf since the last glacial maximum. Earth Planet. Sci. Lett. 142, 4357.

Lambeck, K., 1997. Sea-level change along the French Atlantic and Channel coasts since the time of the Last Glacial Maximum. Palaeogeogr. Palaeoclimatol. Palaeoecol. 129, 1-22.

Lambeck, K., 1998. On the choice of timescale in glacial rebound modelling: mantle viscosity estimates and the radiocarbon timescale. Geophys. J. Int. 134, 647-651.

Lambeck, K., Bard, E., 2000. Sea-level change along the French Mediterranean coast since the time of the Last Glacial Maximum. Earth Planet. Sci. Lett. 175, 203-222.

Lambeck, K., Nakada, M., 1990. Late Pleistocene and Holocene sea-level change along the Australian coast. Palaeogeogr. Palaeoclimatol. Palaeoecol. 89, 143-176.

Lambeck, K., Johnston, P., Smither, C., Nakada, M., 1996. Glacial rebound of the British Isles - III. Constraints on mantle viscosity. Geophys. J. Int. 125, 340-354.

Lambeck, K., Smither, C., Johnston, P., 1998. Sea-level change, glacial rebound and mantle viscosity for northern Europe. Geophys. J. Int. 134, 102-144.

Marcus, E.S., 1991. Tel Nami, a study of a Middle Bronze 2a period coastal settlement. MA thesis, Haifa University, Haifa, 259 pp.

Michelson, H., 1970. The geology of the Carmel coast. Tahal Report, 025/70 (in Hebrew).

Nakada, M., Lambeck, K., 1987. Glacial rebound and relative 
sea-level variations: a new appraisal. Geophys. J. Rev. Astron. Soc. 90, 171-224.

Nakada, M., Lambeck, K., 1988. The melting history of the Late Pleistocene Antarctic ice sheet. Nature 333, 36-40.

Neev, D., Bakler, N., Emery, K.O., 1987. Mediterranean Coasts of Israel and Northern Sinai. , Holocene Tectonism From Geology, Geophysics and Archaeology. Taylor and Francis, New York, $130 \mathrm{pp}$.

Nir, Y., Eldar, I., 1986. Ancient ground-water table in old wells as an indicator of paleo sea-levels and neotectonic changes along the coastal plain of Israel. Geological Survey of Israel Report, GSI/34/86, 28 pp. (in Hebrew).

Nir, Y., Eldar, I., 1987. Ancient wells and their geoarchaeological significance in detecting tectonics of the Israel Mediterranean coastline region. Geology 15, 3-6.

Pirazzolli, P.A., 1991. World Atlas of Holocene Sea-Level Changes, Elsevier Oceanography Series, 58. Elsevier, Amsterdam.

Raban, A., 1981. Recent maritime archaeological research in Israel. Int. J. Nautical Archaeol. Underwater Explor. 10 (4), 287-308.

Raban, A., 1983. Recent maritime archaeological research in Israel. Int. J. Nautical Archaeol. Underwater Explor. 12, 229-251.

Raban, A., 1995. Dor-Yam: Marine and coastal installations at Dor in their geomorphological and stratigraphic context. In: Qedem Reports, Excavations at Dor, Final Report Volume 1A, Areas A and C, Introduction and Stratigraphy (E. Stern, Director), the Institute of Archaeology, The Hebrew University of Jerusalem in cooperation of Israel Exploration Society, pp. 285-354.
Raban, A., Galili, E., 1985. Recent maritime archaeological research in Israel - a preliminary report. Int. J. Nautical Archaeol. Underwater Explor. 14 (4), 321-356.

Reiss, Z., Issar, A., 1961. Contributions to the study of the Pleistocene in the coastal plain of Israel. Subsurface Quaternary correlations in the Tel Aviv region. Isr. Geol. Surv. Bull. 32, 10-28.

Sharvit, J., Galili, E., 1998. Coastal and underwater Survey of Ashkelon. In: Galil, B., Mart, Y. (Eds.), Proceedings of the annual symposium of the Mediterranean continental margin of Israel.

Sivan, D., 1996. Paleogeography of the Galilee coastal plain during the Quaternary. Israel, Geological Survey Report, GSI/18/96, $214 \mathrm{pp}$.

Sivan, D., Galili, E., 1999. Holocene tectonic activity in the Galilee coast and shallow shelf, Israel. A geological and archaeological study. Isr. J. Earth Sci. 48, 47-61.

Sivan, D., Gvietzman, G., Sass, E., 1999. Quaternary stratigraphy and paleogeography of the Galilee coastal plain, Israel. Quat. Res. 51, 280-294.

Sneh, Y., Klein, M., 1984. Holocene sea level changes at the coast of Dor, Southeast Mediterranean. Science 226, 831-832.

Van Andel, T.H., Shackleton, J.C., 1982. Late Paleolithic and Neolithic coastlines of Greece and the Aegean. J. Field Archaeol. 9, 445-454.

Wreschner, E.E., 1983. The submerged Neolithic village Neve Yam on the Israeli Mediterranean coast. In: Masters, P.M., Flemming, N.C. (Eds.), Quaternary Coastlines and Marine Archaeology. Academic Press, London, pp. 325-333. 